\title{
Vester, Shari. 2012. Degrees of Courage. Minneapolis, MN: Mill City Press. 574 pp.
}

\section{Reviewed by Klára Papp, Pennsylvania State University, Hershey, PA}

In her family memoir, or in fact multigenerational matriarchal family saga, Shari Vester creates a moving portrait of her Hungarian family in the twentieth century. Vester's book is 574 pages long and that in itself makes it a family saga. Memoirs by their nature tend not to be so long since they usually cover only an important period in the narrator's life. This book provides an account of what it was like to live in Sopron, Hungary through the destruction wrought by two World Wars and the subsequent Soviet takeover, all through the stories of Vester's grandmother, mother, and herself. The memoir delves into the dark consequences of war and describes the changing roles of women as resulting from sweeping social and cultural developments (with noteworthy similarities to and differences from Éva Pataki's also matriarchal family saga, Ami elveszett - családregény, Budapest: Athenaeum, 2010; and István Szabó's 1999 film Sunshine).

The book is made up of seven chapters, each relating to significant events in the twentieth century and in this family's life, starting from the early nineteen hundreds. Vester does not explicitly base her narrative on historical sources but, presumably, on the oral testimonies and narrations of her grandmother and -- to a greater extent -- her mother, as well as on her own imagination. When asked what inspired her to write her life and family story, Vester stated her wish to pass on the legacy of those who lived in Hungary and those who left it during the difficult and troublesome twentieth century (Vester was interviewed by Erin Davies for her Flashlight Commentary - Literature Reviews from a Late Night Reader blog, at: http://flashlightcommentary.blogspot.co.il, retrieved June 15, 2014).

The novel starts with the funeral of Shari Vester's great grandmother, which takes place at the beginning of the twentieth century in Sopron, in western Hungary. In this chapter, we meet Angela, Shari's grandmother and the oldest daughter of the deceased, and her eight siblings as they take part in their mother's funeral. Angela's father, an emotionally distant man, is devastated at the loss of his wife, and his children are now left without motherly care and emotional support. While her peers worry only about the latest fashion, social gatherings, parties and potential beaux, Angela finds herself at the young age of eighteen thrust into the role of mother and caregiver to her siblings.

A pivotal character in Angela's life and story is the local parish priest, Rev. Henrich, a young and inexperienced priest, who officiates at the funeral. Later, Rev. Henrich tries to support Angela by offering her solace and friendship and by also asking people in the community for help on her behalf. Inevitably, the two become drawn to each other, and mutual attraction soon becomes more than either of them can resist. After their first sexual encounter, Rev. Henrich vows to leave the priesthood and marry Angela, and he leaves for Vienna to ask his superiors for dispensation from the priesthood. In the meantime, Angela develops her skills as a seamstress and finds excuses to visit Vienna to meet with Henrich. She soon becomes pregnant, and when she can no longer conceal her pregnancy, reveals her situation to her father, who reacts with

$($ (c) $)$ EY

ULIS D-Serke 
Papp, Klára. "Vester, Shari. 2012. Degrees of Courage. Minneapolis, MN: Mill City Press. 574 pp.." Hungarian Cultural Studies. e-Journal of the American Hungarian Educators Association, Volume 7 (2014): http://ahea.pitt.edu DOI: 10.5195/ahea.2014.157

anger, especially as Angela refuses to disclose the identity of her lover. Her father consequently evicts her from the family home, barely letting her say farewell to her siblings. Utterly dejected, she finds a small apartment in Vienna, where she supports herself as a seamstress.

In spite of the fact that Henrich was able to persuade the church leaders to support his education while studying to become a teacher, leaving the priesthood and establishing a new family turns out to be much more complicated than either Henrich or Angela imagined. Unfortunately, while finishing his studies, Henrich contracts tuberculosis and goes to a sanatorium to recover, and then disappears from the sanatorium as well as from Angela's life, without letting her know that he fell in love with a nurse at the sanatorium. Meanwhile, Angela gives birth to Lensie (Ilona) in Vienna in 1906 and faces the fate of an unwed mother, including social defamation as well as financial and psychological hardships.

As Lensie grows up, she learns to cope with life's troubles with resilience as she attends a Catholic school. Her classmates treat her with derision, although the nuns and her mother try to protect her. In 1925, at age nineteen, Lensie becomes engaged to Jenö, an ambitious young man eleven years her senior. Angela opposes the marriage because of the age difference between the two and because she thinks that they are not well suited for each other. Despite all obstacles, they persist, and at the age of twenty, Lensie marries Jenő. The couple settles in Sopron and later they have five children; the second of them is Shari, born in 1931, the author of the book.

Shari's narrative, based on her childhood and coming-of-age recollections and dealing with identity issues, is vivid and realistic. Shari described the horror, the bombings, the shortage and other hardships of WWII as she and her family lived them. As for the postwar time, she described various relationships she had and her evolving self-awareness while growing up in communist Hungary. Shari becomes infatuated with a sweetheart, Viktor, and struggles to meet him in secret, thus defying the mores of the times forbidding girls to go anywhere unchaperoned. When in 1950, at the age of nineteen, she is accepted with full scholarship to the University of Economics in Budapest, she breaks up with Viktor because of the compelling allure of the big city. She then struggles to pursue her education with dwindling scholarship support and ends up with a series of boyfriends with whom she experiences disappointments and betrayals.

Shari's descriptions of the oppressive social and political forces under the Rakosi and Nagy 1950s dictatorships are seamlessly woven into her experiences of adolescence and young adulthood. Following the Hungarian Uprising of 1956, Shari crosses the Austrian border by foot at Sopronkeresztúr (Deutschkreuz) and thus becomes one of some 200,000 refugees who were lucky to have made their way to the West. At the urging of a friend, Shari applies at the U.S. Consulate for entry into the country and she is answered positively within a few days. After an initial stay at a transit camp (Camp Kilmer) in New Jersey, she gets a job as a model in Manhattan. Later she is accepted to California Western University at San Diego with full tuition and a place to live on campus, plus a part-time job to cover her personal expenses. She even has a short lived marriage in those early years. She struggles to adjust to life in America, occasionally visiting her family in Hungary and realizing the gradual change she has undergone and the growing differences between her Hungarian family and herself. The book ends with the story of the slow decline and then the deaths of her parents.

In her interview by Erin Davies, Vester expresses her hope that the book will serve as a testimony, for the generations to come, about the hardships and sufferings endured by previous generations of Hungarians. Vester also hopes to raise awareness of Hungary and its history as a Central European country. She feels that today, especially in North America, when one makes a 
casual reference to Hungary, it is likely that only goulash and paprika come to mind and not the turbulent historical events that this country knew in the last century. She therefore stresses her urge to portray Hungary's fate as a country that suffered the loss of two thirds of its territory and one third of its Hungarian speaking population in 1920, German occupation in 1944, and Soviet domination from 1945 to 1989 . When asked by Davies about the historical background on which she based Degrees of Courage, Vester replied that having been born and raised in Hungary, she experienced the history of the country in the flesh, and that her story is drawn from her personal and family experiences. In addition, she made several trips to Hungary to learn more about historical dates, events and prominent personae, especially in the earlier part of the twentieth century, World War I and the interwar period.

For those unfamiliar with Hungarian history in the twentieth century, this book poignantly illuminates central chapters in this history through the lives of one family of three generations of women, while for those familiar with Hungarian history the book is still absorbing and emotionally engaging. The question as to who of the three women or which of the three generations had the greatest courage, as suggested by the book's title, is left to the reader to decide. 